\title{
Microsporidian disease of the invasive amphipod Dikerogammarus villosus and the potential for its transfer to local invertebrate fauna
}

\author{
Karolina Bacela-Spychalska • Rémi A. Wattier • \\ Céline Genton · Thierry Rigaud
}

Received: 6 April 2010/ Accepted: 10 February 2012/Published online: 23 February 2012

(C) The Author(s) 2012. This article is published with open access at Springerlink.com

\begin{abstract}
Invasive species may introduce novel pathogens to a colonised area. Most of the time emerging pathogens are detected a posteriori, but recognition of a priori emergence of an invasive disease by host shift may be useful for predictive purposes. Here, we studied if the microsporidian parasite Cucumispora dikerogammari infecting the invasive Ponto-Caspian amphipod Dikerogammarus villosus, has the potential to become an emergent disease in invaded rivers in Western and Central Europe. We first showed that this parasite decreases the survival of $D$. villosus in the later stages of infection development. However, the host reproduces earlier in response to the infection, which could potentially reduce the negative impact of the parasite on host populations. Cucumispora dikerogammari is able to infect other crustacean species as revealed by our experimental infections. However, field census showed that it was found in other Ponto-Caspian
\end{abstract}

K. Bacela-Spychalska · R. A. Wattier .

C. Genton · T. Rigaud

Laboratoire Biogéosciences, Université de Bourgogne, UMR CNRS 5561, Équipe Écologie Évolutive,

6 boulevard Gabriel, 21000 Dijon, France

Present Address:

K. Bacela-Spychalska ( $\square)$

Department of Invertebrate Zoology and Hydrobiology, University of Lodz, 12/16 Banacha, 90-237 Lodz, Poland

e-mail: karolina@biol.uni.lodz.pl species of amphipods only when it was observed in high prevalence in its native host, and when this host was at moderate frequencies in the community. Therefore, adaptation of $C$. dikerogammari to native gammaridean hosts has probably not been realized in the wild yet. However, since several environmental factors may promote future adaptations of the parasite to novel host species, we suggest $C$. dikerogammari should be included in surveillance networks for emergent disease in freshwater.

Keywords Parasite transmission - Ponto-Caspian species · Cucumispora dikerogammari $\cdot$ Biological invasions $\cdot$ Host community

\section{Introduction}

Emerging or re-emerging diseases can be broadly defined as infectious diseases that recently expanded their geographic or host range, or prevalence (Dobson and Foufopoulos 2001; Jones et al. 2008). The role of biological invasions in the emergence of diseases is still under debate. Some studies suggested that the invasive success of some species is facilitated by the lack of predators and/or pathogens in the newly colonized ecosystems (enemy release hypothesis, Torchin et al. 2003). Indeed, numerous invasive species lose their pathogens during the invasive process. However, other studies show that invasive species introduced novel parasites to new hosts in colonised areas (review in 
Dunn 2009). Host mixing (such as the one occurring when new species colonize a new range) may promote parasite adaptation to novel hosts and therefore the emergence of a new disease (Woolhouse et al. 2005). There is a greater understanding of ecological and evolutionary patterns governing the emergence of diseases and adaptation to novel hosts, thanks to several recent studies (e.g. Woolhouse et al. 2005; Benmayor et al. 2009). However, the emergence of diseases still remain 'inherently' unpredictable (Woolhouse et al. 2005) and most of the time is recognized a posteriori, i.e. after disease emergence (but see Davies and Pedersen 2008). Looking a priori for the probability of emergence by host shift of an invasive disease remains overlooked, despite the fact that such a step may be useful for predictive purposes.

Microsporidia are very common intracellular parasites infecting protists and all animal phyla. Many of them induce infectious diseases (horizontally transmitted), cause huge damage to the host, for example massively infecting muscles, and are lethal (Wittner and Weiss 1999). However, some species are transmitted vertically and are therefore less virulent. In addition vertically transmitted species may cause sexratio distortion and/or have positive impact on host reproduction (Haine et al. 2007; Mautner et al. 2007). Others have a mixed transmission strategy with various degree of virulence (e.g. Agnew and Koella 1997; Vizoso and Ebert 2005; Slothouber-Galbreath et al. 2004). A microsporidian disease has recently been discovered in European rivers associated to the invasive gammarid Dikerogammarus villosus (Crustacea, Amphipoda) (Wattier et al. 2007; Ovcharenko et al. 2010). Dikerogammarus villosus is one of the most invasive freshwater species, colonising major river systems of Western and Central Europe from its Ponto-Caspian origin (Bij de Vaate et al. 2002; Bollache et al. 2004; Grabowski et al. 2007a; Wattier et al. 2007; Bacela et al. 2008). Due to several favourable life-history traits and to its top predator position in the food chain, D. villosus is able to outnumber rapidly other macroinvertebrate species in colonized areas (Dick and Platvoet 2000; Bollache et al. 2004; Van Riel et al. 2006; Pöckl 2007; Grabowski et al. 2007b). Dikerogammarus villosus is the typical host for the microsporidia Cucumispora dikerogammari (Ovcharenko and Kurandina 1987; Wattier et al. 2007, Ovcharenko et al. 2010), which spreads out successfully with its host and was identified in many populations all over Europe (Wattier et al. 2007). Its prevalence was variable between $D$. villosus populations, reaching peaks of about $72 \%$ prevalence in populations where the host has been established for 3-5 years (Wattier et al. 2007). This microsporidium is transmitted between individual hosts mainly horizontally, but its presence in ovaries suggests it can occasionally be vertically transmitted (Wattier et al. 2007; Ovcharenko et al. 2010). Its massive presence in muscles suggests pathogenicity to its host, but no study was dedicated to specifically measure its virulence. Host specificity is only rarely strict in freshwater miscrosporidia: most of the microsporidian parasites infecting gammarids or fish are found across various species (Terry et al. 2003, 2004; El Alaoui et al. 2006; Wattier et al. 2007; Ironside et al. 2008). One may therefore wonder if this microsporidian disease could be an emerging disease in local macro-invertebrate fauna of colonized areas.

The aim of the present study was to estimate a priori if C. dikerogammari has the potential to become an emergent disease in European rivers, by addressing different questions. We first investigated the parasite virulence in its original host by comparing survival, fecundity and dynamic of reproduction of infected $v s$. uninfected $D$. villosus individuals. We then tested experimentally if native potential hosts are susceptible to the foreign parasite. We finally compared the prevalence of $C$. dikerogammari between original hosts and surrounding macroinvertebrate fauna (mainly crustaceans) in seven natural sites with known invasion history of $D$. villosus. Theory predicts that host shift is favoured when the original host species is neither rare nor dominant in the community (Benmayor et al. 2009), therefore the proportion of $D$. villosus in the studied assemblages was also measured.

\section{Materials and methods}

Estimate of microsporidian virulence on D. villosus

Dikerogammarus villosus were sampled in 2008 in the Zegrzynski Reservoir on the Bug River in Zegrze,

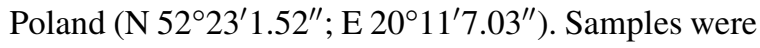
taken with a hydrobiological hand net using the kicksampling technique (Hynes 1954) in the littoral part of the water body where the bottom consisted of stones. 
Only adults were analyzed. Animals for the molecular analysis were sorted in the field and preserved in $100 \%$ ethanol, while individuals used for experiments were transported to the laboratory in tanks with an aerating system. Prior to investigations, all individuals were sexed (presence of penes and characteristic setosity on the flagellar segments of antenna 2 in males, presence of oostegites in females) and measured (linear dimension of the fourth coxal plate; see Bollache et al. 2000) using a stereoscopic microscope (Nikon SMZ 1500) and Lucia G 4.81 software.

To follow the potential effect of the infection on the dynamics of $D$. villosus reproduction, the proportion of breeding females was compared between infected and uninfected animals in two samples: in March, i.e. during the first peak of reproduction in Europe and in July, i.e. during the core of the breeding season. An effect of the infection on fecundity was estimated by comparing the number of eggs in females infected with the number in those not infected. Only females with undamaged brood pouches were analyzed, and, only the third developmental stage was taken into account (Skadsheim 1982). For each infected D. villosus breeding female, we determined the vertical transmission rate of $C$. dikerogammari by extracting and amplifying DNA from a pool of 20 embryos taken from the brood pouch. The infection status was tested by a diagnostic PCR-RFLP method (see below).

To investigate the survival, $D$. villosus taken from the wild were acclimatized in mass for 2 days under standard laboratory conditions $\left(15^{\circ} \mathrm{C} \pm 1\right.$, light:dark cycle $12 \mathrm{~h}: 12 \mathrm{~h}$ ) in aerated tanks filled with dechlorinated, u.v.-treated, tap water and fed with a mixture of commercial frozen chironomid larvae, decaying oak leaves and commercial food pellets for fish. Individuals were then placed in separate pots $(10 \mathrm{cL})$, without food, under the same light and temperature conditions as during acclimatization. Thirty symptomatic (white coloration of the muscles visible through the cuticle, see Ovcharenko et al. 2010) and 60 asymptomatic adult animals were taken randomly from the sample. Twice as many asymptomatic individuals were taken because Ovcharenko et al. (2010) showed that gammarids at the early stage of infection lack the symptoms. Infectious status was later controlled by a PCR-RFLP diagnostic test (see below). Since we checked animals twice a day for survival, DNA extraction from fresh cadaver allowed such a test. We therefore obtained afterwards three categories of hosts: Symptomatic Infected (SI), Asymptomatic Infected (AI) and Uninfected (U), for which survival was followed during 16 days.

\section{Experimental infections}

We first controlled the intensity of horizontal transmission in D. villosus, to determine if cannibalism is the only source of infection. D. villosus used as recipients for parasites came from the unparasitized population of Saone River at St. Jean-de-Losne, France (N $47^{\circ} 5^{\prime} 23,45^{\prime \prime}$; E $\left.05^{\circ} 14^{\prime} 31,63^{\prime \prime}\right)$. Donors of spores were 18 symptomatic $D$. villosus from Zegrze, Poland. Recipient individuals were all kept separately in the laboratory, in the conditions described above.

Two types of experiments on artificial infection were set up. In the first experiment, recipients individuals $(\mathrm{n}=42)$ were fed with a $0.5 \mathrm{~cm}^{3}$ piece of pellet of commercial food for fish (SERA) homogenised with $10 \mu \mathrm{l}$ of a spore suspension consisting in a mix of the 18 spore donors (250,000 spores per $1 \mu \mathrm{l}$, counted under a Nikon Eclipse E600 microscope). Before treatment, the viability and infectivity of the spores were checked by controlling the exhaustion of polar filament on an aliquot of the suspension following Sokolova et al. (2006). In the second experiment, the recipient individuals were fed with infected symptomatic tissues of D. villosus. Each donor individual was cut into three pieces: the first part was conserved in pure ethanol for molecular analysis, and the two remaining were proposed as food for uninfected animals. Control individuals for the two experiments $(\mathrm{n}=28$ and $\mathrm{n}=17$, respectively) received either the same artificial food without the spore suspension or were fed with killed asymptomatic D. villosus previously checked for the absence of infection by PCR-RFLP. Individuals were checked daily for presence of infectious symptoms. Individuals dying during experiment were immediately preserved in pure ethanol, for further molecular analysis of parasite presence. The experiments were conducted for 2 months.

We then tested if two native gammarid species living in eastern France, Gammarus pulex and $G$. roeselii, were sensitive to $C$. dikerogammari infection. The experimental infection was conducted with a protocol similar to the second experiment described above. Twenty adult individuals of each species (sampled in the River Ouche, Dijon, were D. villosus 
is not present) were fed with a piece of a symptomatic $D$. villosus, while twenty control individuals of each species were fed with a piece of uninfected $D$. villosus.

Prevalence of $C$. dikerogammari in D. villosus and associated local macro-invertebrate fauna

Because the probability of parasite sharing is generally higher between phylogenetically-related host species (e.g. Davies and Pedersen 2008), we focussed our study mainly on crustacean assemblages. Samples were gathered in 7 sites where the history of invasion by $D$. villosus is known: 4 in France and 3 in Poland (Table 1). For five sites, the history of prevalence of C. dikerogammari is also known (Wattier et al. 2007, Bacela-Spychalska, unpublished data, Fig. 1). We used a semi-quantitative method and the number of animals collected was corrected by the time spent to collect them (30-180 min according to sites) multiplied by the number of people involved in the sampling (1-3) (Grabowski et al. 2006). All animals were sorted in the field and preserved in 100\% ethanol. All crustaceans were identified to the species level using keys of Eggers and Martens (2001) and Jazdzewski and Konopacka (2002), while other taxa were identified to higher taxonomic levels. DNA was then extracted from animals representative of the assemblage and PCR-RFLP procedure was used to detect $C$. dikerogammari (see below).

\section{Parasite detection and identification (PCR-RFLP)}

For parasite detection, the gammarids were dissected and DNA from muscle tissue was extracted as in Haine et al. (2004). A fragment of the microsporidian $16 \mathrm{~S}$ rDNA was amplified with microsporidian specific primers V1f and 530r following Wattier et al. (2007). PCR reactions were performed in $10 \mu$ reaction mixtures adjusted to a final concentration of $400 \mathrm{nM}$ of each primer, $200 \mu \mathrm{M}$ dNTPs, $0.5 \mathrm{U} / \mu \mathrm{l}$ of Promega Taq polymerase, with buffer according to manufacturer's instructions. The amplification program began with $94^{\circ} \mathrm{C}$ denaturation for $2 \mathrm{~min}$ followed by 34 cycles of $94^{\circ} \mathrm{C}(20 \mathrm{~s}), 57^{\circ} \mathrm{C}(45 \mathrm{~s})$ and $65^{\circ} \mathrm{C}(45 \mathrm{~s})$. The final extension was at $65^{\circ} \mathrm{C}$ for $5 \mathrm{~min}$. The PCR products with the length of $\sim 500 \mathrm{bp}$ were then cut with the VspI restriction enzyme, which cleaves specifically to C. dikerogammari (Wattier et al. 2007).
Statistical analysis

Continuous data were analyzed using linear models when satisfying homocedasticity, after logarithmic transformation when necessary. The best statistical models were obtained by starting with models including all explanatory variables and their two-order interactions, and then proceeding with a backward stepwise simplification of models. Models presented in the results are the one minimising the Akaike Information Criterion (AIC) (Quinn and Keough 2002). Categorical data were analysed using likelihood-ratio $\chi^{2}$ test, or using logistic regressions for multiple explanatory variables, using a similar backward procedure as described above. For the analysis of prevalence (i.e. the proportion of infected individuals among the sampled animals), explanatory variables were the season (March/July), the gender of the individuals (Male/Female) and the size of the individuals. For the analyses of fecundity and proportion of breeding females, explanatory variables were the season, the infection status (Infected/Uninfected) and the size of the individuals.

A proportional hazards model (Cox 1972) was used to compare the survival of the different groups of D. villosus. The effects of infection status, sex, and size were investigated, and a backward procedure as described above was used for the elimination of non significant interactions from the model. To estimate if differences between the 3 infection groups (uninfected, asymptomatic infected and symptomatic infected) were significant, the risk ratios were calculated. A ratio greater than 1 implies that the hazard function increases relative to the reference group, i.e. the survival is lower than in the reference group. A 95\% confidence interval for the risk ratio that does not include 1 is evidence of a significant difference between groups.

All analyses were done with JMP 6.0 Software (SAS Institute Inc.) with $\mathrm{p}$ values $<0.05$ considered as significant.

\section{Results}

Cucumispora dikerogammari in Dikerogammarus villosus and its influence on the host reproduction and survival

The prevalence of the parasite in the 704 adults collected at Zegrze varied with the season and the size 
Table 1 Number of arthropods sampled at each site, and the prevalence of Cucumispora dikerogammari estimated by a diagnostic PCR-RFLP procedure: na not analysed

\begin{tabular}{|c|c|c|c|c|}
\hline Site & Species or group & $\mathrm{n}$ & $\%$ infected $^{\mathrm{a}}$ & C.I. $0.95^{\mathrm{c}}$ \\
\hline Saône at St & D. villosus & 65 & 0.00 & $0-4.50$ \\
\hline Jean & Gammarus tigrinus & 1 & na & na \\
\hline \multirow[t]{8}{*}{ De Losne } & Gammarus roeselii & 1 & na & na \\
\hline & Gammarus pulex & 48 & $0.00 \mathrm{~ns}$ & $0-6.05$ \\
\hline & Crangonyx pseudogracilis & 1 & na & na \\
\hline & Chelicorophium curvispinum & 63 & $0.00 \mathrm{~ns}$ & $0-4.64$ \\
\hline & Asellus aquaticus & 65 & $0.00 \mathrm{~ns}$ & $0-4.50$ \\
\hline & Hemimysis anomala & 2 & na & na \\
\hline & Atyaephyra desmaresti & 1 & na & na \\
\hline & Zygoptera & 1 & na & na \\
\hline Saône at & D. villosus & 242 & 0.41 & $0-1.22$ \\
\hline \multirow[t]{9}{*}{ Pagny-la-Ville } & G. tigrinus & 1 & na & na \\
\hline & G. roeselii & 3 & na & na \\
\hline & C. curvispinum & 69 & $0.00 \mathrm{~ns}$ & $0-4.25$ \\
\hline & A. aquaticus & 4 & na & na \\
\hline & A. desmaresti & 1 & na & na \\
\hline & Ephemeroptera & 2 & na & na \\
\hline & Zygoptera & 3 & na & na \\
\hline & other Diptera & 3 & na & na \\
\hline & Trichoptera & 1 & na & na \\
\hline Saône at & D. villosus & 87 & 1.15 & $0-3.39$ \\
\hline \multirow[t]{9}{*}{ Heuilley } & C. pseudogracilis & 31 & na & na \\
\hline & C. curvispinum & 101 & $0.00 \mathrm{~ns}$ & $0-2.92$ \\
\hline & A. aquaticus & 76 & $0.00 \mathrm{~ns}$ & $0-3.86$ \\
\hline & H. anomala & 84 & na & na \\
\hline & Chironomidae & 7 & na & na \\
\hline & Ephemeroptera & 3 & na & na \\
\hline & Zygoptera & 27 & na & na \\
\hline & Trichoptera & 7 & na & na \\
\hline & Oligochaeta & 1 & na & na \\
\hline \multirow[t]{7}{*}{ Bug at Zegrze } & D. villosus & 237 & 41.35 & $35.08-47.62$ \\
\hline & Dikerogammarus haemobaphes & 28 & $3.57 * * *$ & $0-0.44$ \\
\hline & Chaetogammarus ischnus & 148 & $0.68 * * *$ & $0-1.99$ \\
\hline & Pontogammarus robustoides & 69 & $0.00 * * *$ & $0-4.25$ \\
\hline & C. curvispinum & 42 & $2.38 * * *$ & $0-6.99$ \\
\hline & Chironomidae & 36 & $0.00 * * *$ & $0-7.98$ \\
\hline & Oligochaeta & 73 & $0.00 * * *$ & $0-4.02$ \\
\hline \multirow[t]{3}{*}{ Bug at Nur } & D. villosus & 46 & 15.22 & $4.83-25.59$ \\
\hline & Zygoptera & 79 & na & na \\
\hline & Trichoptera & 46 & $0.00 * *$ & $0-6.30$ \\
\hline \multirow[t]{4}{*}{ Bug at Gnojno } & D. villosus & 81 & 6.17 & $0.93-11.41$ \\
\hline & D. haemobaphes & 1 & na & na \\
\hline & A. aquaticus & 16 & na & na \\
\hline & Heteroptera & 7 & na & na \\
\hline
\end{tabular}


Table 1 continued

\begin{tabular}{llcll}
\hline Site & Species or group & $\mathrm{n}$ & $\%_{\text {infected }}^{\mathrm{a}}$ & ${\text { C.I. } 0.95^{\mathrm{c}}}^{\mathrm{n}}$ \\
& Trichoptera & 99 & na & $0.00^{*}(48)^{\mathrm{b}}$ \\
Zygoptera & 109 & $28.70(94)^{\mathrm{b}}$ & $19.57-37.87$ \\
Rhine at & D. villosus & 250 & na & na \\
& C. ischnus & 2 & $0.00^{* * *}$ & $0-7.98$ \\
\hline
\end{tabular}

${ }^{a}$ The proportion of infected animals was compared within each site, between Dikerogammarus villosus and other crustacean species or insect group (Likelihood-ratio $\chi^{2}$ ). ns $P>0.05$, * $P<0.05$, ** $P<0.01$, *** $P<0.001$

$\mathrm{b}$ The prevalence was estimated on a sub sample, the number of which is given within brackets

c The confidence interval at $95 \%$ is provided. For species where no parasite was observed, the maximal likely frequency of the infection at $P=0.05$ is calculated according to Post and Millest (1991), the minimum frequency being 0

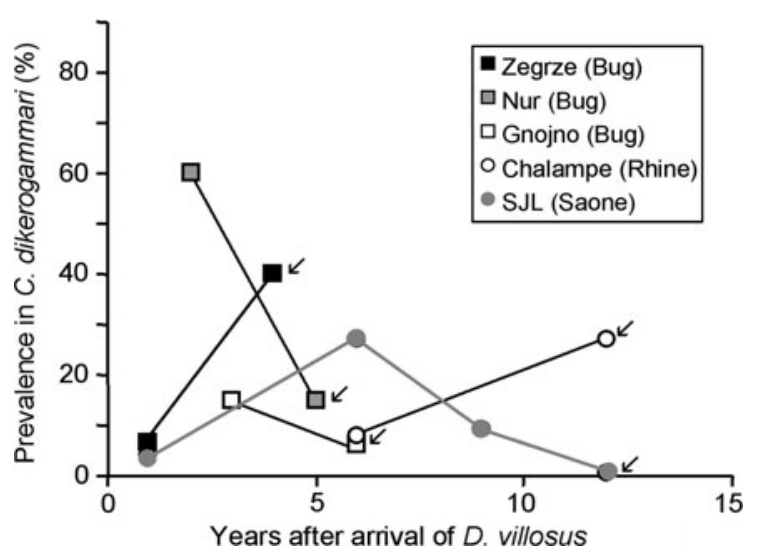

Fig. 1 History of the prevalence of Cucumispora dikerogammari in Dikerogammarus villosus at five sites, relative to the number of years after host colonization (see text for the $D$. villosus colonization dates). For two sites, the parasite prevalence was estimated as earlier as the arrival of the hosts. For three sites, it was estimated for the first time at various times after the host colonization. Arrows indicate the time at which surrounding fauna was analysed in the present study (see Table 1)

of the individual, but was not related to the sex of the host (Logistic regression: season effect: L-R $\chi^{2}=$ 8.61, $P=0.003$, size effect: L-R $\chi^{2}=26.13$, $P<0.0001$, sex effect: L-R $\chi 2=6.10^{-3}, P=0.98$; non-significant interactions were removed from the model). Prevalence was lower in March than in July $(42.66 \%, \mathrm{n}=273$ and $54.74 \%, \mathrm{n}=411$, respectively), and infection probability increased with increasing size of the host.

Infected females started to breed earlier: more infected females were observed among the breeding females at the beginning of the reproductive season, but the reverse pattern was observed during the core of
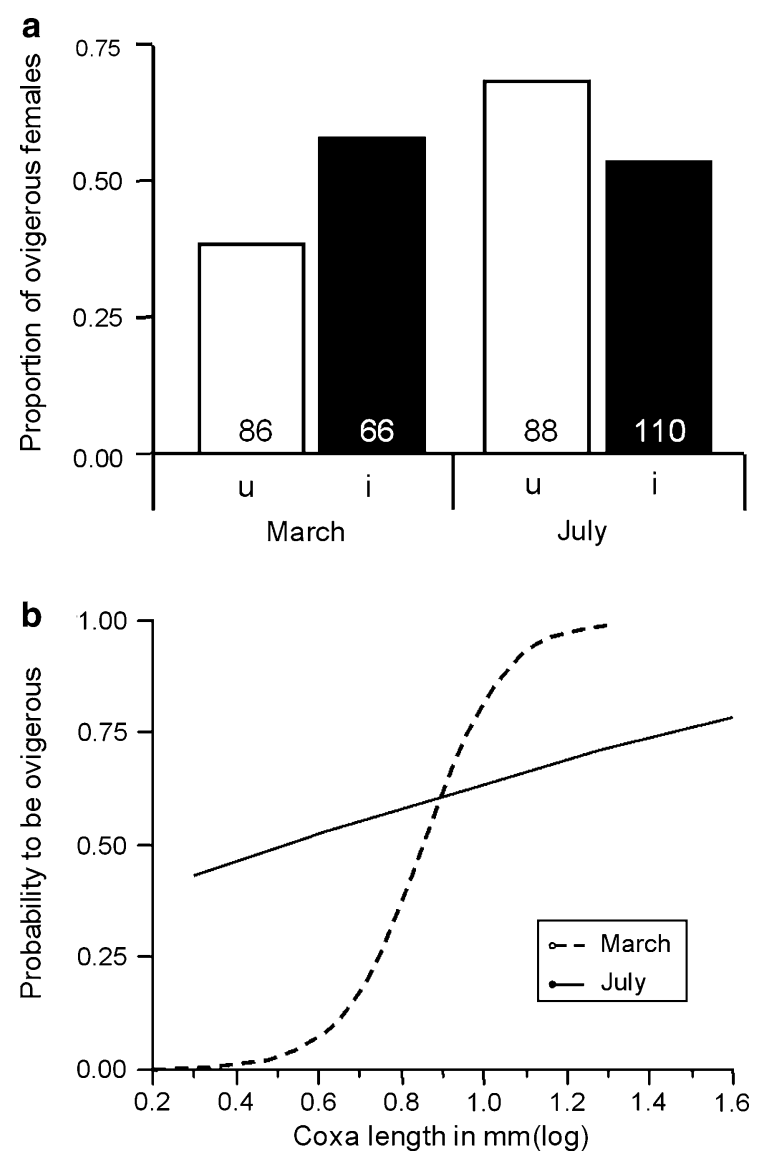

Fig. 2 Proportion of ovigerous (i.e. breeding) Dikerogammarus villosus females according to infection status (u: uninfected; i: infected by Cucumispora dikerogammari) and season (a), and according to their size and season (b). In Fig. 2b, lines were generated by the logistic equations

the breeding season (Fig. 2a; Table 2). The probability of being reproductive also increased with female size, but this pattern was more pronounced in March than in 
Table 2 Logistic regression analyzing the effect of season, infection by Cucumispora dikerogammari and size on the probability of breeding of Dikerogammarus villosus females

\begin{tabular}{lccc}
\hline Source & DF & L-R $\chi^{2}$ & $\mathrm{P}$ \\
\hline Season & 1 & 1.28 & 0.26 \\
Infection & 1 & 0.17 & 0.68 \\
Size & 1 & 56.86 & $<0.0001$ \\
Season $\times$ infection & 1 & 6.79 & 0.009 \\
Season $\times$ size & 1 & 26.179 & $<0.0001$ \\
\hline
\end{tabular}

Non significant interactions were removed after a stepwise procedure

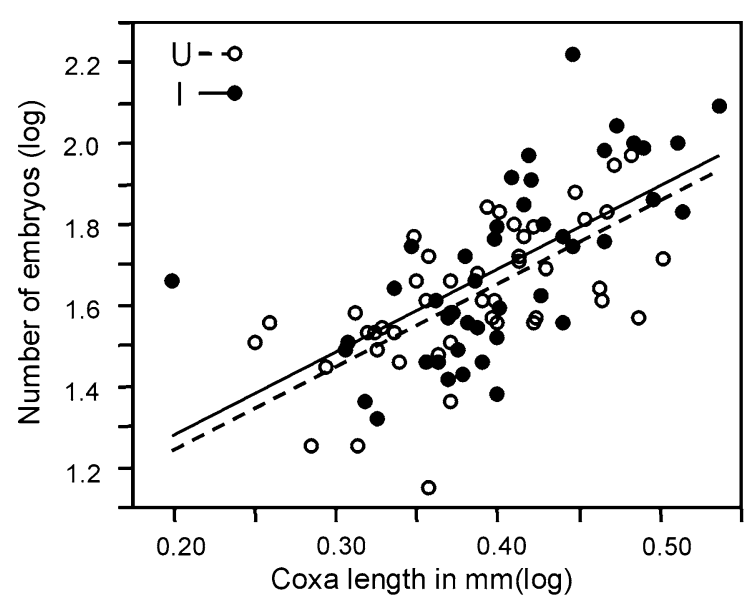

Fig. 3 Fecundity of Dikerogammarus villosus females according to their size (estimated as the length of their fourth coxal plate) and their infection status by Cucumispora dikerogammari. Regression lines are the result of the model with the non significant interaction being removed

July (Table 2; Fig. 2b). Among 99 infected females, $57.5 \%$ transmitted the infection to their brood. An analysis of covariance revealed that the fecundity of $D$. villosus females was mostly explained by their size $\left(\mathrm{F}_{1,87}=61.44, P<0.0001\right)$, but not by infection by C. dikerogammari $\left(\mathrm{F}_{1,87}=1.29, P=0.26\right)$ (Fig. 3).

The survival of $D$. villosus under laboratory conditions was strongly influenced by the infection status (L-R $\chi 2=62.98,2$ d.f., $P<0.0001$ ) (Fig. 4). The risk ratios indicate that symptomatic infected animals had a significantly lower survival rate than control uninfected animals (risk ratio $=7.10,95 \%$ confidence interval: 4.18-13.13), while the difference between asymptomatic infected and uninfected animals was non-significant during our short survey (risk ratio $=0.64$, confidence interval: $-1.07-0.19$ ). The survival of the animals was also different according to

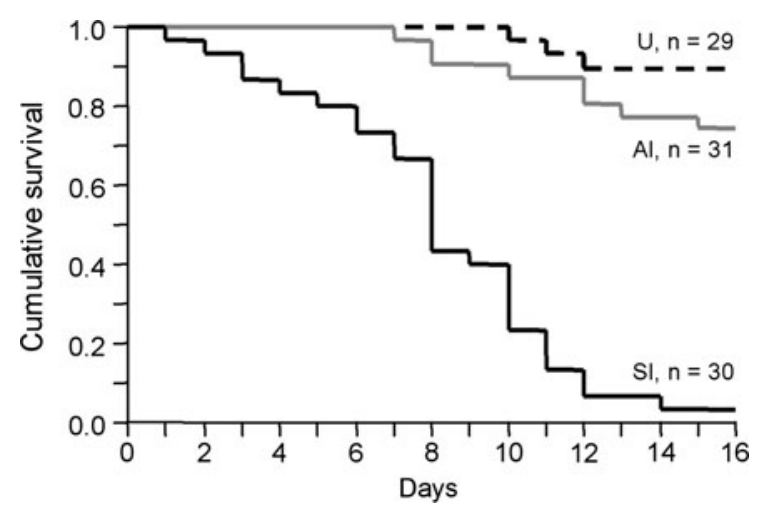

Fig. 4 Cumulated survival of Dikerogammarus villosus according to their infection status ( $U$ asymptomatic uninfected, $A I$ asymptomatic infected, SI symptomatic infected)

their gender, females surviving better than males (L-R $\chi^{2}=5.72,1$ d.f., $P<0.02$, results not showed). Neither the gammarid size nor the interactions between the different factors were significant, and were removed from the model.

The rate of horizontal transmission of Cucumispora dikerogammari in native and foreign hosts in experimental infections

None of the control $D$. villosus exposed to uninfected pellet of fish food or uninfected gammarids were found infected after 60 days. They were therefore grouped into a single control group in further analysis. Infection of $D$. villosus was much more efficient when exposed to infected D. villosus tissues compared to infected pellets of fish food (L-R $\chi^{2}=16.76, P<0.0001$ ) (Fig. 5). First symptoms were visible after 43 day postexposure. The infection of the two other gammarid species was possible, Gammarus roeselii showing a higher level of infection than G. pulex (Fig. 5). This difference was nevertheless non significant (L-R $\chi^{2}=1.93, P=0.16$ ). Both $G$. pulex and $G$. roeselii were significantly less infected than the host of origin, D. villosus (L-R $\chi^{2}=14.57, P=0.0001$ and $\mathrm{L}-\mathrm{R}$ $\chi^{2}=5.28, P=0.02$, respectively) (Fig. 5).

\section{Prevalence in natura of $C$. dikerogammari} in D. villosus and associated local macro-invertebrate fauna

In D. villosus, the prevalence of $C$. dikerogammari was variable between the different sampling sites 


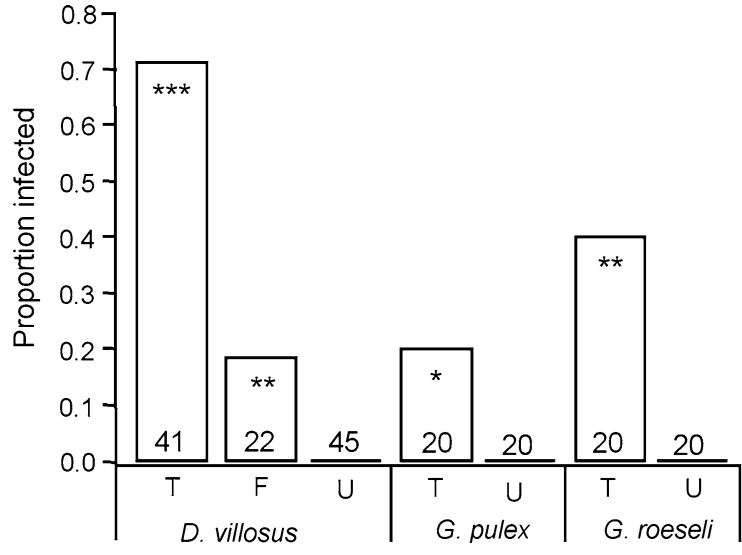

Fig. 5 Proportion of individuals infected by Cucumispora dikerogammari after experimental infections, according to the recipient species and the type of the experimental exposure. T: individuals exposed to infected Dikerogammarus villosus tissues, F: individuals exposed to infected artificial food, U: individuals exposed to uninfected $D$. villosus tissues or uninfected artificial food. Number of individuals in every treatment are indicated on the graph. The asterisk in the bars indicates the level of significance of Likelihood-ratio $\chi^{2}$ testing the difference in prevalence between exposed individuals and their respective controls. $* P<0.05, * * 0.001<P<0.01$, $* * * P<0.0001$

(Table 1). The parasite was very rare in the Saône river (France), while it was known to be highly prevalent 6 years ago (Fig. 1). In the more recently colonized Bug River (Poland), the prevalence was variable according to sites, but higher than in France (Table 1). At these sites, the prevalence of the infection was either increasing or decreasing, without obvious patterns according to colonization dates by the host (Fig. 1). In a French site of the Rhine river, where the colonization by $D$. villosus is as ancient as in the Saône River (1997, see Bollache et al., 2004), the prevalence was high, and microsporidian prevalence increased between the two last sampling dates (Table 1; Fig. 1). Across sites, we found a positive correlation between $D$. villosus density and $C$. dikerogammari prevalence (Spearman $\rho=0.76, P=0.048$, Fig. 6a).

Cucumispora dikerogammari infected other macroinvertebrate species only at Zegrze. Its prevalence in these species was much lower than in the original host at that site (Table 1), and only Ponto-Caspian crustacean species were infected, including Chelicorophium curvispinum, an amphipod that does not belong to the superfamily Gammaroidea (Eggers and Martens 2001). It is worth noting that Pontogammarus robustoides, another invasive gammarid originating
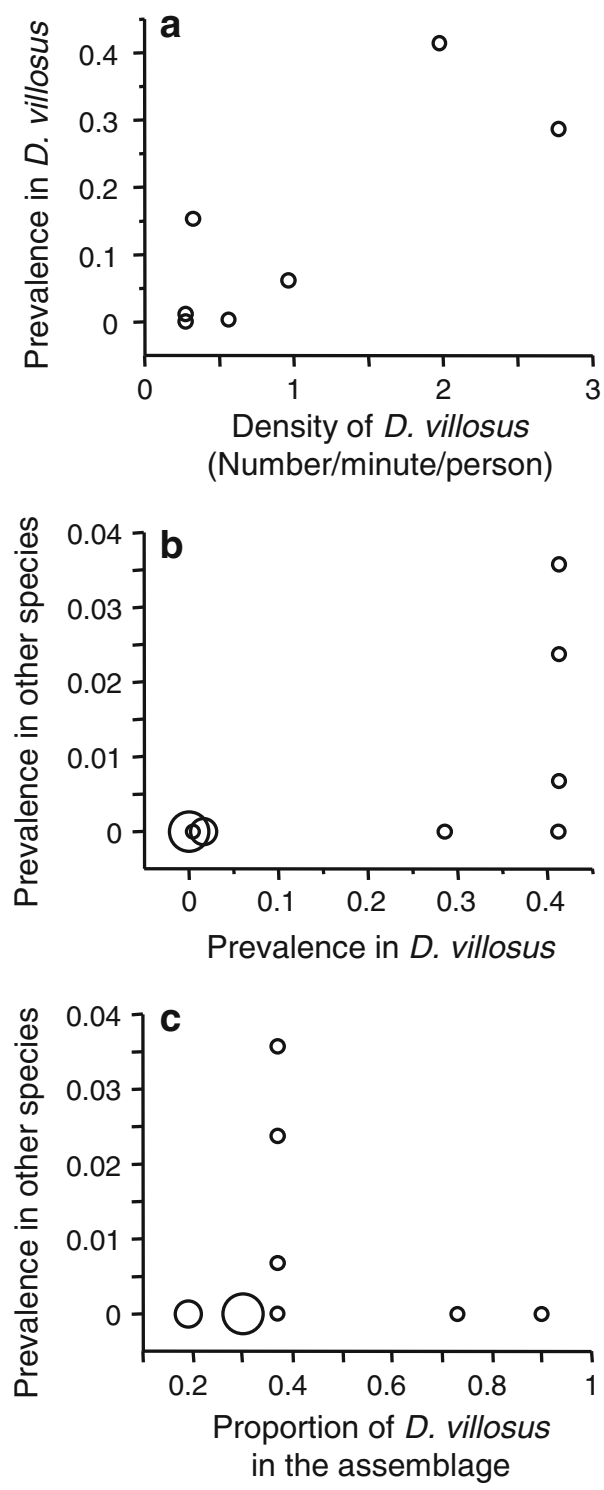

Fig. 6 Prevalence of Cucumispora dikerogammari in its initial host, Dikerogammarus villosus according to host density (a), and in other arthropods found in the assemblages described in Table 1, according to the prevalence in the initial host (b) and the proportion of the initial host in the assemblage (c). The sizes of the dots are proportional to the number of overlapping data (1, 2 or 3 data)

from the same region as D. villosus, was not found infected with this microsporidium. Insects were apparently uninfected by the microsporidia. The Zegrze site, where other species of crustaceans were found infected, corresponded to the site where both the prevalence in the initial host was very high (Fig. 6b, 
$\rho=0.69, P=0.02$ ), and the proportion of the initial host in the assemblage was intermediate (Fig. 6c).

\section{Discussion}

Prevalence, transmission and virulence of Cucumispora dikerogammari in Dikerogammarus villosus

Our study confirmed previous results from Wattier et al. (2007) and Ovcharenko et al. (2010) that C. dikerogammari is a microsporidian parasite frequently infecting the populations of $D$. villosus outside its native range of distribution.

The prevalence of $C$. dikerogammari in D. villosus from the Bug River was higher in summer than in early spring. This may be explained by higher water temperature in summer, which directly induces faster development of the parasite within the host (Ebert 1995), or it may be a result of higher transmission due to higher predation rate. Since we showed that the main transmission route is cannibalism (see below), this phenomenon is likely. At high temperatures, predation rate is higher in D. villosus (Van der Velde et al. 2009), because of faster metabolic rate, which may increase the probability of preying on infected cospecific species. We also found that larger gammarids had a higher probability of being infected, confirming previous results (Ovcharenko et al. 2010). This can be a result of higher predation and necrophagy rate observed in larger (therefore older) gammarids than in younger ones, which fed more frequently on detritus than on animal remnants (Van Riel et al. 2006).

We showed that $C$. dikerogammari is virulent only in the later stages of the disease: only symptomatic animals experienced a lower survival, while infected but asymptomatic showed the same survival rate as uninfected ones. This parasite is therefore not neutral for its host, and one would predict that a high prevalence associated to a high virulence may regulate the population dynamics of the host (Tompkins and Begon 1999) and consequently mediate the invasion success (Dunn et al. 2009). However, our results suggest that $D$. villosus females can plastically adjust their sexual maturation when infected. Such a shorter time to maturity would limit the impact of virulence by allowing host reproduction before death (e.g. Polak and Starmer 1998; Chadwick and Little 2005).
Therefore, C. dikerogammari should have no major impact on the dynamics of $D$. villosus populations, or its probability of invasive success. In fact, only an unrealistic high virulence could be a factor limiting the establishment of an invasive host (Drake 2003). The rapid spread and establishment of D. villosus (e.g. Bollache et al. 2004) confirms that microsporidia did not limit it despite high prevalence (Wattier et al. 2007).

Despite the confirmation of some vertical transmission (Ovcharenko et al. 2010), our new investigation suggests $C$. dikerogammari is mainly horizontally transmitted. First, we have the direct evidence that necrophagy on infected conspecifics leads to high transmission rates (around 70\%). This infection route is more efficient in C. dikerogammari than described in the microsporidia Pleistophora mulleri which infect another amphipod, Gammarus duebeni celticus (around 20\%, MacNeil et al. 2003). Second, we found a positive link between parasite prevalence and host density (Fig. 6a), suggesting that transmission is host density-dependant, a pattern not expected if vertical transmission is the main route of transmission. Third, we have an indirect suggestion that vertical transmission is weak: the proportion of infected young individuals is lower than the proportion of infected individuals observed in large adults; in case of vertical infection as the main route of transmission, such a phenomenon should not have been observed. Nevertheless, even a small amount of vertical transmission could be helpful for parasite establishment in an invasive population, because it reduces parasite loss after the demographic bottleneck experienced by the host during the invasive process (Slothouber-Galbreath et al. 2010). Cucumispora dikerogammari therefore benefits from both modes of transmission.

Does Cucumispora dikerogammari adapt to new hosts in colonized communities?

Our results showed that the "compatibility filter" (Combes 2001) is open for a number of crustacean species for $C$. dikerogammari. In addition with species tested in experimental infections (G. pulex and G. roeselii), other gammaroid species (D. haemobaphes, Chaetogammarus ischnus) and one amphipod outside the superfamily Gammaroidea (Chelicoropium curvispinum) were found infected in the wild. Cucumispora dikerogammari may also infect other 
gammarid species in the native range of $D$. villosus: it was observed in the Ponto-Caspian Obesogammarus crassus and C. ischnus (Ovcharenko and Kurandina 1987; Ovcharenko and Vita 1996), even if these observations have to be taken cautiously because they were made by light microscopy only. The prevalence of C. dikerogmmari in these species was much lower than in its typical host. The diverse success in experimental infection of typical host vs. atypical hosts suggests some host specificity of C. dikerogammari, as observed in other microsporidian species (i.e. Hatcher et al. 2005). Therefore, conditions where the disease emergence can occur are relatively limited to ecological situations where prevalence is high in the invasive host while the host is not the dominant species in the assemblage.

Taken together, these results suggest that the opportunities for the microsporidian transmission to other hosts are restricted to a narrow window of time in the chronology of invasion, when several ecological conditions are fulfilled. In the first steps of the invasion, these amphipods exclude mostly through predation other macroinvertebrate species (Van der Velde et al. 2002; Bollache et al. 2004). There is therefore only a weak probability for resident hosts to encounter the parasite in the early invasive steps. Even when the transfer occurred, the prevalence in other hosts is weak, at least much weaker than in the original host, which contrasts with the relatively high sensitivity of some indigenous gammarids as revealed in experimental infections. It means that, even in the most favourable ecological conditions, the transmission to new hosts is probably limited. This could be due to the fact that $D$. villosus is a highrank predator in food-webs (e.g. Van Riel et al. 2006; Bollache et al. 2008). Because encounters with other macroinvertebrate species always lead to their predation by D. villosus (Dick et al. 2002), there is little opportunity for other crustaceans or macroinvertebrates to predate on $D$. villosus. Therefore, even if a given local macroinvertebrate is susceptible to the disease, the "encounter filter" (Combes 2001) remains most of the time closed for new hosts. In these conditions, the selective pressure would be too low for the parasite to adapt its life cycle to these new hosts (Benmayor et al. 2009).

In conclusion, $C$. dikerogammari cannot yet be considered as an emerging disease, because it cannot effectively adapt to new hosts in the long term. While we did not test the impact on foreign hosts, there is only a weak probability that the low prevalence observed in these species in the wild can cause serious damages to local populations. This microsporidium has nevertheless potential for emergence, for several reasons. First, foreign hosts are sensitive to the infection at a higher rate than what we can observe in the wild. Second, the dynamics of $D$. villosus invasion is compatible with a pattern of recurrent colonization waves in rivers of Western Europe (Wattier et al. 2007). Therefore, recurrent colonization in a given site may maintain genetic diversity in parasites and promote adaptability to novel hosts. In addition, the rivers where $D$. villosus occurs are the largest rivers in Europe that are generally classified as polluted water bodies (e.g. Panov et al. 2009). Water pollution decreases natural immune defenses, which may increase the probability of parasite transfer to novel host species (McCallum and Dobson 2002). The potential for these eventualities should encourage watershed managers to include $C$. dikerogammari in their surveillance networks.

Acknowledgments Karolina Bacela-Spychalska was funded by a post-doctoral grant from the Région Bourgogne (grant \# 07HCP 59) and the French Foreign Office (Programe Egide, grant \# 604506E). We thank Mark Gillingham for having read the last version of this manuscript.

Open Access This article is distributed under the terms of the Creative Commons Attribution License which permits any use, distribution, and reproduction in any medium, provided the original author(s) and the source are credited.

\section{References}

Agnew P, Koella JC (1997) Virulence, parasite mode of transmission, and host fluctuating asymmetry. Proc R Soc London B 264:9-15

Bacela K, Grabowski M, Konopacka A (2008) Dikerogammarus villosus (Sowinsky 1894) (Crustacea, Amphipoda) enters Vistula: the biggest river in the Baltic basin. Aquat Inv 3:95-98

Benmayor R, Hodgson DJ, Perron GG, Buckling A (2009) Host mixing and disease emergence. Curr Biol 19:764-767

Bij de Vaate A, Jazdzewski K, Ketelaars HAM, Gollasch S, Van der Velde G (2002) Geographical patterns in range extension of Ponto-caspian macroinvertebrate species in Europe. Can J Fish Aquat Sci 59:1159-1174

Bollache L, Gambade G, Cezilly F (2000) The influence of micro-habitat segregation on size assortative pairing in Gammarus pulex (L.) (Crustacea, Amphipoda). Arch Hydrobiol 147:547-558 
Bollache L, Devin S, Wattier RA, Chovet M, Beisel JN, Moreteau JC, Rigaud T (2004) Rapid range extension of the pontocaspian amphipod Dikerogammarus villosus (Crustacea, Amphipoda) in France: potential consequences. Arch Hydrobiol 160:57-66

Bollache L, Dick JTA, Farnsworth KD, Montgomery WI (2008) Comparison of the functional responses of invasive and native amphipods. Biol Lett 4:166-169

Chadwick W, Little TJ (2005) A parasite-mediated life-history shift in Daphnia magna. Proc R Soc London B 272: 505-509

Combes C (2001) Parasitism. The ecology and evolution of intimate interactions. University of Chicago Press, Chicago and London

Cox DR (1972) Regression models and life tables. J Roy Stat Soc B 34:187-220

Davies TJ, Pedersen AB (2008) Phylogeny and geography predict pathogen community similarity in wild primates and humans. Proc R Soc London B 275:1695-1701

Dick JTA, Platvoet D (2000) Invading predatory crustacean Dikerogammarus villosus eliminates both native and exotic species. Proc R Soc London B 267:977-983

Dick JTA, Platvoet D, Kelly DW (2002) Predatory impact of the freshwater invader Dikerogammarus villosus (Crustacea : Amphipoda). Can J Fish Aquat Sci 59:1078-1084

Dobson A, Foufopoulos J (2001) Emerging infectious pathogens of wildlife. Phil Trans R Soc Lond B 356:1001-1012

Drake JM (2003) The paradox of the parasites: implications for biological invasion. Proc R Soc London B 270:S133-S135

Dunn AM (2009) Parasites and biological invasions. Adv Parasitol 68:161-184

Ebert D (1995) The ecological interactions between a microsporidian parasite and its host Daphnia magna. J Anim Ecol 64:361-369

Eggers TO, Martens A (2001) Bestimmungsschlüssel der Süßwasser-Amphipoda Crustacea) Deutschlands. Lauterbornia 42:68

El Alaoui H, Gresoviac SJ, Vivares CP (2006) Occurrence of the microsporidian parasite Nucleospora salmonis in four species of salmonids from the Massif Central of France. Folia Parasitol 53:37-43

Grabowski M, Konopacka A, Jazdzewski K, Janowska E (2006) Invasions of alien gammarid species and retreat of natives in the Vistula Lagoon (Baltic Sea, Poland). Helgol Mar Res 60:90-97

Grabowski M, Bacela K, Konopacka A (2007a) How to be an invasive gammarid: comparison of life history traits. Hydrobiologia 590:75-84

Grabowski M, Jazdzewski K, Konopacka A (2007b) Alien Crustacea in Polish waters: amphipoda. Aquat Inv 2:25-38

Haine ER, Brondani E, Hume KD, Perrot-Minnot M-J, Gaillard M, Rigaud T (2004) Coexistence of three microsporidia parasites in populations of the freshwater amphipod: evidence for vertical transmission and positive effect on reproduction. Int J Parasitol 34:1137-1146

Haine ER, Motreuil S, Rigaud T (2007) Infection by a verticallytransmitted microsporidian parasite is associated with a female-biased sex ratio and survival advantage in the amphipod Gammarus roeseli. Parasitology 134:1363-1367

Hatcher MJ, Hogg JC, Dunn A (2005) Local adaptation and enhanced virulence of Nosema granulosis artificially introduced into novel populations of its crustacean host, Gammarus duebeni. Int J Parasitol 35:265-274

Hynes HBN (1954) The ecology of Gammarus duebeni Lilljeborg and its occurrence in fresh water in western Britain. J Anim Ecol 23:38-84

Ironside JE, Wilkinson TJ, Rock J (2008) Distribution and host range of the microsporidian Pleistophora mulleri. J Eukaryot Microbiol 55:355-362

Jazdzewski K, Konopacka A (2002) Invasive Ponto- Caspian species in waters of the Vistula and Oder basins and the southern Baltic Sea. In: Leppäkoski E, Gollasch S, Olenin $\mathrm{S}$ (eds) Invasive Aquatic Species of Europe - Distribution Impacts and Management. Kluwer Academic Publishers, Dordrecht, pp 384-398

Jones KE, Patel NG, Levy MA, Storeygard A, Balk D, Gittleman JL, Daszak P (2008) Global trends in emerging infectious diseases. Nature 451:990-994

MacNeil C, Dick JTA, Hatcher MJ, Fielding NJ, Hume KD, Dunn AM (2003) Parasite transmission and cannibalism in an amphipod (Crustacea). Int J Parasitol 33:795-798

Mautner SI, Cook KA, Forbes MR, McCurdy DG, Dunn AM (2007) Evidence for sex ratio distortion by a new microsporidian parasite of a corophiid amphipod. Parasitology 134:1567-1573

McCallum H, Dobson A (2002) Disease, habitat fragmentation and conservation. Proc R Soc London B 269:2041-2049

Ovcharenko NA, Kurandina DP (1987) New species of microsporidia from amphipods of the Dnieper basin. Parazitologiya 21:710-715

Ovcharenko NA, Vita I (1996) New data on microsporidium Nosema dikerogammari. Parazitologiya 30:333-338

Ovcharenko M, Bacela K, Wilkinson T, Ironside J, Rigaud T, Wattier RA (2010) Cucumispora dikerogammari n. gen. (Fungi: Microsporidia) infecting the invasive amphipod Dikerogammarus villosus: a potential emerging disease in European rivers. Parasitology 137:191-204

Panov VE, Alexandrov BG, Arbaciauskas K, Binimelis R, Copp GH, Grabowski M, Lucy F, Leuven RS, Nehring S, Paunovic M, Semenchenko V, Son MO (2009) Assessing the risks of aquatic species invasions via european inland waterways: from concepts to environmental indicators. IEAM 5:110-126

Pöckl M (2007) Strategies of a successful new invader in European fresh waters: fecundity and reproductive potential of the Ponto-Caspian amphipod Dikerogammarus villosus in the Austrian Danube, compared with the indigenous Gammarus fossarum and G. roeseli. Freshw Biol 52:50-63

Polak M, Starmer WT (1998) Parasite-induced risk of mortality elevates reproductive effort in male Drosophila. Proc R Soc London B 265:2197-2201

Post RJ, Millest AL (1991) Sample-size in parasitological and vector surveys. Parasitol Today 7:141

Quinn GP, Keough MJ (2002) Experimental Design and Data Analysis for Biologists. Cambridge University Press, New York

Skadsheim A (1982) The ecology of intertidal amphipods in the Oslofjord. The life cycles of Chaetogammarus marinus and C. stoerensis. Mar Ecol 3:213-224

Slothouber-Galbreath JGM, Smith JE, Terry RS, Becnel JJ, Dunn AM (2004) Invasion success of Fibrillanosema 
crangonycis, n.sp., n.g.: a novel vertically transmitted microsporidian parasite from the invasive amphipod host Crangonyx pseudogracilis. Int J Parasitol 34:235-244

Slothouber-Galbreath JGM, Smith JE, Becnel JJ, Butlin RK, Dunn AM (2010) Reduction in post-invasion genetic diversity in Crangonyx pseudogracilis (Amphipoda: Crustacea): a genetic bottleneck or the work of hitchhiking vertically transmitted microparasites? Biol Inv 12:191-209

Sokolova YY, Lange CE, Fuxa JR (2006) Development, ultrastructure, natural occurrence, and molecular characterization of Liebermannia patagonica n. g., n. sp., a microsporidian parasite of the grasshopper Tristira magellanica (Orthoptera: Tristiridae). J Inv Pathol 91: 168-182

Terry RS, MacNeil C, Dick JTA, Smith JE, Dunn AM (2003) Resolution of a taxonomic conundrum: an ultrastructural and molecular description of the life cycle of Pleistophora mulleri (Pfeiffer 1895; Georgevitch 1929). J Eukaryot Microbiol 50:266-273

Terry RS, Smith JE, Sharpe RG, Rigaud T, Littlewood DTJ, Ironside JE, Rollinson D, Bouchon D, MacNeil C, Dick JTA, Dunn AM (2004) Widespread vertical transmission and associated host sex-ratio distortion within the eukaryotic phylum Microspora. Proc R Soc London B 271: 1783-1789

Tompkins DM, Begon M (1999) Parasites can regulate wildlife populations. Parasitol Today 15:311-313

Torchin ME, Lafferty KD, Dobson AP, McKenzie VJ, Kuris AM (2003) Introduced species and their missing parasites. Nature 421:628-630
Van der Velde G, Nagelkerken I, Rajagopal S, Bij de Vaate A (2002) Invasions by alien species in inland freshwater bodies in Western Europe: The Rhine Delta. In: Leppäkoski E, Gollasch S, Olenin S (eds) Invasive Aquatic Species of Europe - Distribution. Kluwer Academic Publishers, Dordrecht, Impacts and Management, pp 360-372

Van der Velde G, Leuven RSEW, Platvoet D, Bacela K, Huijbregts MAJ, Hendriks HWM, Kruijt D (2009) Environmental and morphological factors influencing predatory behaviour by invasive non-indigenous gammaridean species. Biol Inv 11:2043-2054

Van Riel MC, Van der Velde G, Rajagopal S, Marguiller S, Dehairs F, Bij de Vaate A (2006) Trophic relationships in the Rhine food web during invasion and after establishment of the Ponto-Caspian invader Dikerogammarus villosus. Hydrobiologia 565:39-58

Vizoso DB, Ebert D (2005) Phenotypic plasticity of host-parasite interactions in response to the route of infection. J Evol Biol 18:911-921

Wattier RA, Haine ER, Beguet J, Martin G, Bollache L, Musko IB, Platvoet D, Rigaud T (2007) No genetic bottleneck or associated microparasite loss in invasive populations of a freshwater amphipod. Oikos 116:1941-1953

Wittner M, Weiss LM (1999) The Microsporidia and Microsporidiosis. ASM Press, Washington, DC

Woolhouse MEJ, Haydon DT, Antia R (2005) Emerging pathogens: the epidemiology and evolution of species jumps. Trends Ecol Evol 20:238-244 